\title{
The Implementation of Stunting Prevention Program during COVID-19 Pandemic in Pandeglang Regency
}

\author{
Shinta Novelia ${ }^{1 *}$, Rosmawaty Lubis ${ }^{2}$, Linda Yuliani ${ }^{3}$, Hadrian Marta ${ }^{4}$ \\ 1,23Midwifery Department, Universitas Nasional Jakarta, shinta.novelia@civitas.unas.ac.id (Corresponding Author) \\ ${ }^{4}$ Directorate General of Regional Development, The Ministry of Home Affairs of Indonesia
}

\begin{abstract}
Article Info:
Submitted:

04-08-2021

Revised:

05-11-2021

Accepted:

08-11-2021

DOI:

https://doi.org/10.53713/nhs.v1i3.46

ABSTRACT

The nutritional status of pregnant women greatly affects the health and development of the fetus. Impaired growth in the womb can cause low birth weight, which triggers stunting. Stunting is a condition of toddlers who have short body size and are not suitable for age caused by malnutrition from both mother and child. The purpose of this study was to determine the implementation of stunting prevention programs during the COVID-19 pandemic at the work area of the Banjar Health Center, Pandeglang Regency in 2021. The study used in this study was a survey descriptive study with a cross sectional approach. The sample in this study was 100 respondents using SPSS with a frequency distribution table using univariate analysis. the results showed that $72 \%$ pregnant women get the counselling class during pregnancy, 93\% pregnant women received supplementary food (PMT), 81\% pregnant women consumed moringa leaves. Prevention of stunting during the Covid-19 pandemic greatly affects the program activities carried out by the Banjar Health Center. It is hoped that this research can provide information, especially to pregnant women and the public, about the importance of preventing stunting since pregnancy.
\end{abstract}

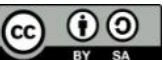

This work is licensed under CC BY-SA License.

Keywords: class of pregnant women; additional food for pregnant women; stunting; moringa leaves

\section{INTRODUCTION}

Stunting is described as chronic undernutrition status during growth and development since early life. This situation is represented by a z-score of height for age (TB/U) less than -2 standard deviations based on the growth standards of the WHO [WHO, 2019]. Indonesia occupies the fifth position in the number of stunting in the world. Stunting is a condition of toddlers who have a short body size and are not suitable for age caused by malnutrition of the mother and child (Ministry of Health of the Republic of Indonesia, 2018). Children who experience stunting can experience impaired physical, mental, cognitive and intellectual development so that children are not able to learn optimally. Stunting children have low cognitive abilities, if not treated before reaching the age of five years, it can have an impact into adulthood and are at risk of death, and stunting adult women are at risk of giving birth to children with low birth weight (Suliastiningsih \& Madi 2013).

The nutritional status of pregnant women greatly affects the health and development of the fetus. Impaired growth in the womb can cause low birth weight (WHO, 2014). The length of the baby's birth is also associated with the incidence of stunting. Research in Kendal shows that babies with short birth lengths are at high risk of stunting in toddlers (Meilyasari \& Isnawati, 2014).

The purpose of stunting prevention counseling is so that the community understands how important the 1000 first day of life (HPK) period is for the lives of children and the community itself, knows how and is motivated to implement it so that the First 1000 Days of Life period is successful for mothers and children (Ministry of Health of Indonesia, 2014). In the context of handling Covid 19, the government has taken policy steps, including refocussing and reallocating the budget as regulated in the instructions of the Minister of Home Affairs of the Republic of Indonesia Number 1 of 2020; Minister of Home Affair Decree no 40 of 2020 "guidelines for the preparation of the 2021 APBD" where stunting is a priority for local governments; the basis for why stunting is a national priority is stated in the 2020-2024 RPJM (MidTerm National Development Plan) (Karnavian, 2020).

The most decisive intervention to reduce stunting prevalence therefore needs to be carried out on 1,000 first day of live (HPK) of toddlers. Some of the factors that cause stunting include poor parenting practices, including a lack of 
maternal knowledge about health and nutrition before and during pregnancy, as well as after the mother gives birth (Oktarina, \& Sudiarti, 2013). Some facts and information showing that toddlers who do not receive exclusive breastfeeding and complementary foods for breast milk (MP-ASI), have limited health services, including ANC-Ante Natal Care (health services for mothers during pregnancy (Mugianti, Mulyadi, Anam \& Najah, 2018). Post Natal Care and quality early learning, lack of household/family access to nutritious food, and lack of access to clean water and sanitation are also causes of stunting. Poor sanitation conditions will increase the incidence of illness that can trigger stunting among toddlers. Some of intervention which could prevent the stunting are the supplementary feeding for pregnant women, strengthening the pregnancy class or health education and also consuming moringa leaves. Moringa leaves are a good source of vitamins and minerals for the body. Moringa leaves are an alternative to overcome cases of malnutrition in Indonesia.

Pandeglang is one of the regency that are included in the stunting locus (Carolin et al., 2021; Wuryanti, 2021). In 2018, the prevalence of stunting was $38.5 \%$, which include around 8,303 stunting toddlers. The stunting locus in Pandeglang including 10 (ten) villages located in 6 (six) sub-districts. Seeing this situation, the Pandeglang district government issued the Pandeglang Regent Regulation Number 28 of 2019 concerning the Acceleration of Stunting Reduction in Pandeglang and formed the Regent's Decree Number 440/Kep.265-Huk/2019 concerning the Coordination Team for the Acceleration of Stunting Reduction in Pandeglang. Thus, the researchers will conduct a study entitled. "Implementation of the Stunting Prevention Program During the Covid-19 Pandemic in Pandeglang Regency".

\section{METHOD}

The research was a quantitative descriptive research approach. The population in this study was all pregnant women in Pandeglang Regency Banten Province in January-December 2020 which consists of 100 pregnant women. The Banjar Health Centre was selected as the study site due to the reate of stunting is still high. The sample was total population with an accidental sampling technique; 100 pregnant women in January-December 2020 in the working area of the Banjar Health Center who were included in the inclusion and exclusion criteria. In this study, the research variables were counseling classes for pregnant women, supplementary feeding (PMT) for pregnant women, and moringa leaves consumption. A questionnaire was used to assess the variabels. A descriptive statistic was used to analyze percentage of each variable.

\section{RESULT}

Table 1. The class counselling for pregnant women at the work area of Banjar Health Centre

\begin{tabular}{ccc}
\hline Class counselling & $(\mathrm{n})$ & $(\%)$ \\
\hline Not implemented & 28 & 28.0 \\
\hline Implemented & 72 & 72.0 \\
\hline Total & 100 & 100.0 \\
\hline
\end{tabular}

From table 1., it is known that from 100 respondents who were pregnant, the majority of respondents, 72 people or $72 \%$, stated that midwives did counseling for pregnant women.

Table 2. Feeding Supplementation (PMT) for pregnant women at the work area of Banjar Health Centre

\begin{tabular}{ccc}
\hline Feeding supplementation & $(\mathrm{n})$ & $(\%)$ \\
\hline Not implemented & 7 & 7.0 \\
\hline Implemented & 93 & 93.0 \\
\hline Total & 100 & 100.0 \\
\hline
\end{tabular}

From table 2, it is known that from 100 pregnant women respondents, the majority of respondents, 93 people or $93 \%$ stated that midwives gave PMT to pregnant women. 
Table 3. Moringa leaves consumption among pregnant women at the work area of Banjar Health Centre

\begin{tabular}{|c|c|c|}
\hline Feeding supplementation & (n) & $(\%)$ \\
\hline Not Comsumed & 19 & 19.0 \\
\hline Consumed & 81 & 81.0 \\
\hline Total & 100 & 100.0 \\
\hline
\end{tabular}

From table 3., it is known that out of 100 pregnant women respondents, the majority of respondents, 81 people or $81 \%$ stated that pregnant women consumed Moringa leaves.

\section{DISCUSSION}

From table 1., it is known that from 100 respondents who were pregnant, the majority of respondents, 72 people or $72 \%$, stated that midwives did counseling for pregnant women. This is reinforced by the respondents who said that the pregnant women's class counseling was carried out $(72 \%)$ but there were also respondents who said that the pregnant women's class counseling was not carried out $(28.0 \%)$.

The results of this study are in line with research conducted by Dwiputri (2019), that pregnant women in the village of Nagrog feel the benefits of the results of counseling pregnant women by implicating it in daily life, counseling for pregnant women is very influential on the incidence of stunting, behavior of pregnant women In checking pregnancy and maintaining diet are aspects that must be considered.

The researcher assumes that the counseling class for pregnant women is an activity that can be felt the benefits for themselves and especially for the fetus they contain. The pregnant women's class counseling activities are very influential on the incidence of stunting, pregnant women become more aware of the material by exchanging ideas and can change the way pregnant women think themselves which are obtained from counseling pregnant women.

From table 2., it is known that from 100 pregnant women respondents, the majority of respondents, 93 people or 93\% stated that midwives gave PMT to pregnant women. This is reinforced by the presence of respondents who said PMT for pregnant women was given to get results (93\%) but there were also respondents who said it was not given (7.0\%).

The results of this study are in line with research conducted by (Bronchetti et al., 2019). that economic status is one of the indirect factors that has a relationship with purchasing power and the choice of food with good nutritional value. Therefore PMT is given to pregnant women who come from poor families. Unbalanced nutrient intake is one of the factors that directly affect stunting. The movement of giving healthy food is an intervention for habituation of healthy food and healthy living habits and the lack of knowledge of mothers about the dangers of stunting causes the number of children with stunting to increase every year in various regions in Indonesia. Researchers assumed that PMT for pregnant women is aimed at meeting the nutritional needs of the women during pregnancy and will have a major impact on the health of the women and fetus. With good nutrition, it will reduce the occurrence of chronic energy deficiency in the women and reduce the incidence of stunting caused by low birth wight babies.

From table 3., it is known that out of 100 pregnant women respondents, the majority of respondents, 81 people or $81 \%$ stated that pregnant women consumed Moringa leaves. Moringa leaves are food ingredients with high nutritional value, especially iron (Joyce et al., 2021; Novelia et al., 2020; Sefarico et al., 2015; Suzana et al., 2017). Iron in 100 grams of Moringa leaves is $7 \mathrm{mg}$, when floured it becomes $28.2 \mathrm{mg}$. Protein and iron levels in Moringa processed foods are getting better. It has gained popularity over the years (Sahay, Yadav \& Srinivasamurthy, 2017). There is immense scope for foods that can impart health benefits beyond traditional nutrients. Moringa oleifera (Drumstick tree) is one such tree having enormous nutritional and medicinal benefits. It is rich in macro and micro nutrients like protein, carbohydrate, calcium, phosphorus, potassium, iron, vitamins, beta carotene and other bioactive compounds which are important for normal functioning of the body and prevention of certain diseases. Most of the parts of Moringa oleifera including leaves, flowers and seeds are edible and other parts like bark, pods have use in biodiesel production and water purification. Moringa oleifera has tremendous therapeutic properties including anticancer, antiulcer, antimicrobial, antioxidant. Various researches have concluded that Moringa should be used as functional ingredient in food products.

The previous study claimed that the administration of Moringa oleifera extract during pregnancy prevents the incidence of stunted growth in children (Kusmawati \& Supriyadi, 2021). Researchers assumed that consuming Moringa leaves is one of the efforts to prevent stunting in pregnant women as proved byBy regularly consuming Moringa leaves, it affects the babies born, the babies will become healthier and the possibility of stunting in children is very small. Moringa leaves contain complete vitamins and minerals. Not only that, Moringa leaves also contain amino acids. From 
Moringa leaves, pregnant women can get more nutrients, especially sources of vitamin $A$, vitamin $C$, vitamin $E$, protein, calcium and potassium.

\section{CONCLUSION}

It can be concluded that the Stunting Prevention Program During the Covid-19 Pandemic in the Banjar Health Center Work Area, Pandeglang Regency in 2021 was implemented well. It can be analysed by the results of the study as follow $72 \%$ pregnant women get the conselling class during pregnancy, $93 \%$ pregnant women received supplementary food (PMT), and $81 \%$ pregnant women consumed moringa leaves. There is a need for further socialization regarding stunting prevention techniques during the COVID-19 pandemic as an effort to improve maternal and child health and reduce stunting rates. Nutrition interventions to improve maternal and child health is a main priority. These interventions are urgently needed to improve the nutritional intake of pregnant women and children; however, they should be affordable and appropriate. The prevalence of stunted growth in Indonesia is still a major problem that should be solved. Administering moringa leaves on pregnant women would have a good impact on both the mother and child

\section{REFERENCES}

Bronchetti, E. T., Christensen, G., \& Hoynes, H. W. (2019). Local food prices, SNAP purchasing power, and child health. Journal of health economics, 68, 102231.

Carolin, B. T., Siauta, J. A., Amamah, N., \& Novelia, S. (2021). Analysis of Stunting among Toddlers at Mauk Health Centre Tangerang Regency. Nursing and Health Sciences Journal (NHSJ), 1(2), 118-124.

Joyce, L. Kundaryanti, R., \& Novelia, S. (2021). The Effect of Moringa Oleifera on Hemoglobin Level in Pregnancy. Nursing and Health Sciences Journal (NHSJ), 1(2), 136-141.

Katmawanti, S., \& Supriyadi, F. M. (2021). Is instant porridge with a high calcium content based on Moringa oleifera as an alternative baby food to prevent stunting in Indonesia?. Journal of Public Health Research, 10(2).

KARNAVIAN, M.T. (2020). PERATURAN MENTERI DALAM NEGERI REPUBLIK INDONESIA NOMOR 40 TAHUN 2020 TENTANG PEDOMAN PENYUSUNAN RENCANA KERJA PEMERINTAH DAERAH TAHUN 2021.

Meilyasari, F., \& Isnawati, M. (2014). Faktor risiko kejadian stunting pada balita usia 12 bulan di Desa Purwokerto Kecamatan Patebon, Kabupaten Kendal (Doctoral dissertation, Diponegoro University).

Mugianti, S., Mulyadi, A., Anam, A. K., \& Najah, Z. L. (2018). Faktor penyebab anak stunting usia 25-60 bulan di Kecamatan Sukorejo Kota Blitar. Jurnal Ners dan Kebidanan (Journal of Ners and Midwifery), 5(3), 268-278.

Novelia, S., Dewi, A., Melinasari, S., Widowati, R., \& Carolin, B. T. (2020). Iron and Orange Extract on Hemoglobin among Anemic Pregnant Women in Nusa Tenggara Barat in 2018. Asian Community Health Nursing Research, 2(1), 8-12.

Oktarina, Z., \& Sudiarti, T. (2013). Faktor risiko stunting pada balita (24-59 bulan) di sumatera. Jurnal gizi dan pangan, 8(3), 177180.Sulistianingsih, A., \& Madi Yanti, D. A. (2016). Kurangnya asupan makan sebagai penyebab kejadian balita pendek (stunting). Jurnal Dunia Kesehatan, 5(1), 77123

Sahay, S., Yadav, U., \& Srinivasamurthy, S. (2017). Potential of Moringa oleifera as a functional food ingredient: A review. Magnesium (g/kg), 8(9.06), 4-90.

Serafico, M. E., Perlas, L. A., Magsadia, C. R., Desnacido, J. A., Viajar, R. V., Rongavilla, E. O., ... \& Trinidad, T. P. (2015, November). Efficacy of Malunggay (Moringa oleifera) leaves in improving the iron and vitamins $A$ and $B$ status of Filipino schoolchildren. International Symposium on Moringa 1158 (pp. 293-302).

Suzana, D., Suyatna, F. D., Andrajati, R., Santi, P. S., \& Mun'im, A. (2017). Effect of Moringa oleifera leaves extract against hematology and blood biochemical value of patients with iron deficiency anemia. Journal of Young Pharmacists, 9(1), S79

WHO. (2014). WHA global nutrition targets 2025: Stunting policy brief. Geneva: World Health Organization

World Health Organization. (2019). Nutrition Landscape Information System (NLIS) country profile indicators: interpretation guide.

Wuryanti, S. (2021). Relationship Between Maternal Education and Knowledge on Coverage of Exclusive Breastfeeding in Ten Stunting Locus Villages in Pandeglang District, Banten. Indonesian Journal of Medical Sciences and Public Health, 2(1), 5561. 